Volume 5 Issue 2, June 2018

\title{
Responsibilities Of Notary In Tradding And Purchase Agreement (PPJB) In Semarang
}

\begin{abstract}
Febrika Rizki Andini ${ }^{1}$ and Umar Ma'ruf $^{2}$
Abstract. This study discussed how to be the responsibility of Notary to the authentic agreement making, which studied further is the Agreement of Tradding and Purchase Agreement. This study used sociological juridical analysis approach, with data obtained through literature and interviews, then the data were analyzed qualitatively. From the result of this study, it is agreed that the duties and authority of Notary by making a personal agreement which has been formed in Article 15 of Act No.30 Of 2004 concerning Notary Position. In this case, the notary is responsible for all agreements he/she has made. Agreement PPJB is made for the introduction and as a legal bridge to conduct the next legal screening, namely Agreement of Tradding and purchase to be read and signed in the vicinity of Notary. PPJB shall be made on the basis of the parties' persecution and prevention of default from either party. Because the Agreement of PPJB is an authentic agreement and made by or in the presence of a Notary then by itself the agreement becomes notary agreement. The power of its protection corresponds to the frequency of authentic agreements. The suggestion that can be given from this study is to further manage the Tradding and purchase agreement in Regulation, especially for the land issues. So that all parties used the Tradding and purchase agreement as engagement can be more secured.
\end{abstract}

Keywords: Responsibility; Notary; Tradding and Purchase Agreement (PPJB).

\section{Introduction}

Business activities are growing rapidly to the extent that we are facing today. The increased of public demand on legal certainty and the development of business activity drives on the need of services from Officials (general) in the field of making evidence to ensure legal certainty.

Any person who argues that he or she makes rights or to uphold his or her own right or denied the rights of others, refers to, distort, and defend the provisions, as the provisions of Article 1865 of the Civil Code ${ }^{3}$. The provisions contained in Article 1865 of the Civil Code which may be used as evidence, proof with witnesses, confessional allegations, and oaths. Proof of writing may be in the form of authentic agreement or underhand agreement. Thus, the strongest agreements will be used for as legal proof by the society, it is deemed necessary, ie, authentic agreements made by or before a Notary.

One of the powers granted to a Public Notary as a general duty is to make a Agreement of Original in addition to the authority prescribed by law. The authentic agreement according to article 1868 of the Civil Code becomes a agreement made by the official which the form is determined by law. With the authority granted by the State to the authorities as stipulated in in article 15 of Act 3 of Notary Position

\footnotetext{
${ }^{1}$ Master of Notary's Student Sultan Agung Islamic University (UNISSULA) Semarang email : febrika.rizki@gmail.com

${ }^{2}$ Lecturer of Faculty of Law UNISSULA

${ }^{3}$ Herlien Budiono 2017 Dasar Teknik Pembuatan Akta Notaris Bandung:Citra Aditya Bakti. P. 1
} 
number 30 of 2004 (State Gazette Of 2004 Number 117) jo Act No.2 Of 2014 (LN Of 2014 Number 03) last Act No.30 Of 2004, the notary has a responsibility in performing his/her position. Related to notary authority, that is included in UUJN Number 30 Of 2004 jo Act No.2 Of 2014, Article 15 paragraph (1) state that:

"Notary authorized to make the agreement authenticity of all actions, agreements, and determination required by legislation and/or desired by the stakeholders to be stated in the Agreement authentic, guaranteeing the creation date of the Agreement, giving gross, copy and quote agreement, all of it along the making of the agreement is not assigned or excluded to any other official or other person as defined by law ".

Furthermore, in addition to the authority in paragraph (1), especially in paragraph (2) letter ( $f)$, the Notary is authorized to make agreement related to land.

Humans are social beings who never lose to interact with other human beings in the life of society. One form of interaction in civil relations is with the agreement made between the parties on a certain matter, the agreement contains contract in accordance with the needs of the parties.

Legal institution and human are as legal subjects who can perform legal acts as the exercise of rights and obligations. Legal acts that may be committed by persons and legal entities as legal subjects, for example: Tradding and purchase agreements, Tradding and purchase engagement, rent agreements, borrowing and lending agreements, and entering into employment agreements. ${ }^{4}$

The arrangement of existing agreements under the Law is contained in the book III of the Civil Code. The terms of the Agreement are described in Article 1313 of the Civil Code, namely the Agreement is the Act by which one or more persons commit themselves to one or more persons. From this event, a legal relationship exists between two or more persons called the Engagement in which there is a right and obligation of each party. Agreement is the source of the engagement.

In the Tradding and Purchase Agreement, there are two Parties. The first is seller and the second is the buyer. To perform the binding, both parties must obtain the conformity, in this case the seller will sell his goods, and the buyer will buy goods from the seller. The definition of Tradding and Purchase is regulated in Article 1457 of the Civil Code. The Tradding and purchase is an agreement whereby one party handed over the object it possesses and the other receives and pays the item for Tradding. The object herein referred to herein is the goods which may be the object of the Tradding and Purchase Agreement, only the tradable goods shall be subject matter of approval under the provisions of Article 1332.

The binding of the Purchase Agreement is a preliminary agreement on a land purchase and/or building agreement which the agreement will be made and signed before Land Agreement Official (PPAT). The binding Tradding and purchase agreement (SPA) that the parties will make buying and selling has been bound and already have rights and obligations to fulfill and cons accomplishment achievement as agreed in a binding Tradding and purchase.

In connection with the above matters, the binding Tradding and purchase agreement is not regulated in the legislation relating to land rights. The position and how the force of law binding Tradding and purchase agreement is sometimes questionable on the

\footnotetext{
${ }^{4}$ Yulies Tiena Masriani 2012 Pengantar Hukum Indonesia Jakarta Sinar Grafika P.22
} 
implementation of the Tradding and purchase of land rights. In practice, the agreement always does not go according to the agreement desired by the parties.

Based on the above description, then in this paper studied: Why is needed to make the Agreement of Tradding and Purchase Agreement (PPJB) by Notary? and What is the responsibility of Notary to the making of the Tradding and purchase agreement (PPJB)?

\section{Research Methods}

In this research, the author used a method of sociological juridical approach. Tamahana stated that socio-legal studies are addressed to Law and Society Studies ${ }^{5}$ According to F.X. Adji Samekto, Social legal studies conceptualize law as the norm and simultaneously as reality. ${ }^{6}$ Judicial approach is an approach that is taken or used to be a reference in highlighting the problems of the legal aspects applicable. Judicial approach is as an approach to the rules of law relating to the legal acts concerning the making of the authentic namely Agreement Tradding and Purchase Agreement (SPA) in Semarang city.

The sociological approach is intended as an attempt to approach the problem under study by the nature of the law which is real or in accordance with reality in society.

The sociological juridical approach is the approach used to provide a qualitative description of the responsibility of Notary to the making of Agreement of Tradding and Purchase Agreement (PPJB) in Semarang City.

\section{Discussion}

\subsection{The need for a Tradding and Purchase Agreement}

The Tradding and purchase binding agreement (PPJB) is a preliminary agreement made by prospective sellers and prospective buyers on an agreement basis before the Tradding and purchase is done. This agreement is required to secure the interests of sellers and potential buyers and minimize any disputes that may arise in the future. The Tradding and purchase binding agreement (PPJB) of the house was conducted prior to the occurrence of the Tradding and purchase legal event (AJB).

PPJB as a preliminary agreement is not regulated in the Civil Code, but its existence in accordance with the provisions of Act No. 1 of 2011 on Housing and Settlements (as lex specialis) which requires a preliminary agreement to buy and sell. In case that the object of Tradding and purchase is still in the process development, then the preliminary agreement of Tradding and purchase is further stipulated by the Decree of State Minister of Public Housing No. 9 of 1995 concerning Guidance of Tradding and Purchase Bond, meaning that substance in PPJB as preliminary agreement must be in accordance with what is in Ministry of Kemenpera No 9 of 1995.

The contents of the PPJB is a statement to provide something (for example: the prospective seller will provide the transfer of ownership of the land and the building thereon to the prospective buyer, if the payment has been paid off) and or do

\footnotetext{
${ }^{5}$ Anis Mashdurohatun, Redyanto Sidji, Gunarto and Mahmutarom, Factors Causing Banking Cyber Crime in Indonesian, International Journal of Economic Research, Volume 14 Number 15 2017, p.295

${ }^{6}$ Ibid.
} 
something (for example: the prospective buyer shall repay the repayment at the agreed time) to other parties relating to an object before ownership moves from seller to buyer. In addition, the PPJB contain can also be about not doing something, for example the prospective seller is prohibited to sell the land to another party.

As a preliminary agreement, there is an associated legal act and inherent after the making of PPJB, namely the act of legal buying and selling. The provisions of Article 1457 of the Civil Code state: "The Tradding and purchase is an agreement, whereby the one party binds himself to surrender a material, and the other to pay the promised price."

PPJB is a consensual agreement, meaning the agreement is born when both parties reach agreement on the object (movable or immovable) and the price even though at that time the goods have not been delivered and the price is not fully paid (Article 1320 paragraph (1) jo Article 1458 KUH Civil).

Based on the above description that has been written author, that the Agreement of Tradding and Purchase Agreement (PPJB) is necessary and important to both parties namely the seller and buyer because this agreement including authentic agreement so that if there is incompatibility from one party, then the other party gets protection law. This PPJB Agreement is very important because this agreement can be a legal bridge. This PPJB Agreement is used as a preliminary agreement to assist in selling and purchasing, although the PPJB has not been specifically regulated, but in making such agreements can use the legal principle based on the Civil Code.

\section{Responsibility of Notary in making of Agreement of Tradding and Purchase Agreement (PPJB)}

Responsibility is an act done by every individual based on one's obligations or calling. That attitude indicates that a person has a very high caring and honesty. the circumstances in which the obligation to bear all things, so obligated to bear, bear responsibility, bear everything or give an answer and bear the consequences.

Position is a field of work or task deliberately created by the rule of law for the purposes and functions of certain and continuous as a permanent employment environment.

The responsibility of the notary itself if in the review of Act No.30 Of 2004 Jo Act No.2 Of 2014 on the Notary's Office is very closely related to the duties and work of a notary. Thus, because in addition to making an authentic agreement, the notary is also assigned and responsible for carrying out legalization and registration (legalization and waarmerken) of letters/agreements made under the hands of the parties. In connection with the authority that must be owned by a Notary is only allowed to run his position in the area that has been determined and stipulated in the Law of the Notary and within the jurisdiction the Notary has the authority. If the provision is not observed, the agreement made by the Notary becomes invalid. The authority possessed by the Notary includes four (4) things as follows:

- Notary must be authorized as long as it concerns the agreement;

- Notary must be authorized as long as the people are the concerned party;

- Notary must be authorized as long as to where, where the agreement was made;

- The notary must be authorized as long as the time of the agreement is made.

Notary authorities other than those contained in Article 15 paragraph (1) of Act No.30 Of 2004 concerning Public Notary Offices are described in Article 15 paragraph (2) of 
Act No.30 Of 2004 concerning Notary Position explaining that a notary also has authority for:

- Authorize signatures and specify the date of the letter under the hand by registering in a special book; Explanation: this provision is a legalization of the underhand agreement made solely by an individual or by parties on paper stamped simply by way of registration in a special book provided by a notary.

- Record the letters under the hand by registering in a special book;

- Make copies of the original letters under the hand in the form of copies containing the description as written and illustrated in the corresponding letter;

- Certify a photocopy match with the original letter;

- Provide legal counseling in relation to the making of the agreement;

- Make agreements related to land and make agreement minutes of auctions. ${ }^{7}$

Based on the above description, the Notary has the authority to make the Agreement of PPJB pursuant to Article 15 of Act No.30 Of 2004 regarding Notary Position. Further, the responsibility of Notary in the former and existing law, although it is not clearly regulated how a Public Notary as a public official accountable legally if he made a mistake in making the agreement.

In making the Agreement, the Notary makes with the parts specified in the Notary's office law, namely: Beginning Agreement/Head of Agreement (title agreement, number of agreement, hours, day, date, month and of, full name and place of Public Notary ), the agreement (the identity of the parties, the status of the act of confrontation, the contents of the agreement which is the will and desire of the parties, and the identity of the witnesses), and the end of the agreement (description of the agreement, the description of the signer and the description of the absence of the change of agreement).

Related to the above description, the authentic agreement made by Notary has the strongest and fullest strength of evidence having an important role in every legal relationship in the life of the community. So that in the notarial agreement is fully responsible for the agreement he made.

\section{CLOSING}

\subsection{Conclusion}

- The Agreement of Tradding and Purchase Agreement (PPJB) is necessary and important to both parties ie sellers and buyers, because this agreement is an authentic agreement so that if there is any misappropriation of one party, the other shall have legal protection. This PPJB Agreement is very important because this agreement can be a legal bridge. This PPJB Agreement is used as a preliminary agreement to assist in selling and purchasing, although the PPJB has not been specifically regulated, but in making such agreements can use the legal principle based on the Civil Code (Civil Code).

- Related to the above description, the authentic agreement made by Notary has the strongest and fullest strength of evidence having an important role in every legal relationship in the life of the community. So that in the notarial agreement is fully responsible for the agreement he made.

\footnotetext{
7 Habib Adjie Hukum Notaris Indonesia (Tasir Tematik Terhadap UU No. 30 Tahun 2004 Tentang Jabatan Notaris) op.cit. p. 73-74.
} 
- Notary in carrying out his duties and authorities is fully responsible for legal acts that will arise in the future and even responsible morale as a professional of the notary's office. In addition, Notary is also responsible Civil and Criminal.

\subsection{Suggestions}

- To maintain trust and to protect the public, Notary should be more careful in making Notarill agreement so that no mistakes happen.

- We recommend that the Regulation concerning the agreement of Tradding and purchase binding exists, so there is a special regulation, not only guided by the Civil Code.

\section{References}

[1] Anis Mashdurohatun, Redyanto Sidji, Gunarto and Mahmutarom, Factors Causing Banking Cyber Crime in Indonesian, International Journal of Economic Research, Volume 14 Number 152017.

[2] Budiono Herlien 2017 Dasar Teknik Pembuatan Akta Notaris PT. Citra Aditya Bakti Bandung.

[3] Harsono Boedi 1992 Tinjauan Hukum Pertanahan Diwaktu Lampau, Sekarang dan Masa Akan Datang Makalah National Seminar on Notary in the HUT UUPA XXXII, Yogyakarta.

[4] Lumban Tobing.G.H.S. 1991 Pengaturan Jabatan Notaris PT. Erlangga Jakarta.

[5] Mahmud Peter Marzuki 2010 Penelitian Hukum PT. Kencana Jakarta.

[6] Tiena Yulies Masriani 2012 Pengantar Hukum Indonesia Sinar Grafika Jakarta.

[7] Yahyah Harahap 2000 Segi-segi Hukum Perjanjian Alumni Bandung.

[8] Yuni Ahdiana Lestari dan Endang Yuriani 2008 Dasar-Dasar Pembuatan Kontrak dan Akad Library University of Muhammadiyah Yogyakarta. 